\title{
Multifaceted Effects of Migration for Sustainable Future
}

\author{
Lal Bahadur Pun
}

\begin{abstract}
Migration has become a global phenomenon because the modern means of transportation has reduced the time of travel. It has not only been soaring globally but also it has been becoming intense in Nepal as well. In the context of Nepal, migration from village towards frontier proximities, towns and city centers has been increasing on everyday basis, which is a stumbling block for sustainable future of both origin and recipient communities because it is associated with social, economic, environmental and institutional attributes of the origin and recipient communities. In this field, very few attempts have been made by academia, professional and concerned authorities focusing on the effects of migration for sustainable future. Considering this reality, I attempted to explore the twofold effects of migration in both origin and recipient communities pleading the stories of three research participants such as one non-migrant and two migrants. In this paper, I implanted ethnographic methods to inscribe the stories of research participants. For this, I employed conversational interview and observation techniques. In addition to this, I put my theoretical positionality on the side of the migration pessimistic school of thought putting the migration optimistic school of thought away to reveal the negative results of migration. Thus, the stories of both non-migrant and migrants have been implored in informal settings. From the sustainable point of view, the departure of people created social, economic, environmental and institutional threats in the origin as well as recipient communities.
\end{abstract}

Keywords: migration, sustainable future, stories, origin communities, recipient communities

\section{Introduction}

Enigmatically, migration is to leave old place to settle in the new one (Central Bureau of Statistics [CBS], 2014); Gartaula \& Niehof, 2013; Gurung, 2001; Lee, 1966; Nepal Demographic Health Survey [NDHS], 2011), because it is an inseparable part of human society (Subedi, 1993). For the regimentation in the new community, the people think and plan to move away from the origin community. Thus, the migrants are those individuals and families, who are on the move (Inchley, 2014). Academically, where the migrants move from; where they move to; why such movement occurs; how migrants pave the way forward; and what the effects of migration are in both origin and recipient communities, are the research agendas. Pertinently, migration occurs, while individuals or households always 'want to make their life prosperous liberating from the hardship life of the home community' (Parajuli, 2008). Usually, migrant's intention is to make life comfortable in the new community. Most of them want to make material life better (Ravenstein, 1889). Almost all individual and household migrants have been enjoying with material facilities in the new community but the negative effects of migration in the origin and recipient communities are not taken into consideration as the challenges for the sustainable future. Experiences show that as much as the intensity of migration increases, the multiple threats in the origin and recipient communities appear. This part is not much focused by the academia, government authorities and individuals. From this paper, I attempted to discover the negative effects of migration in both origin and recipient communities. In the subsequent sections, I have discussed about the research participants, field engagement and methodological pathway. Likewise, I have focused on the negative effects of migration on social, economic, environmental and social institutions, which can be encompassed under 'the migration pessimistic school of thought' (de Haas, 2014); as I do not take insights from the migration optimistic school of thought. Thus, I have placed my positionality in the negative facets of migration in the text. At the end, I have presented the insights of this paper.

\section{Knowing the Research Participants}

On the basis of 'criterion sampling' (Creswell, 2007), I purposively selected three research participants. I have implored the stories of a non-migrant of Bharse and each one migrant from Butwal and Kathmandu. The first research participant is a local research participant of Bharse. The second and third research participants have been living in Butwal and Kathmandu respectively. From Bharse, I have selected Akash Thapa (male, aged 63). Akash is a local resident. He is a retired school principal. He has been spending his retired life in his own village, Bharse. The intention of selecting him is to take information of the local context and garner his personal experiences. Likewise, the second research participant is Tara Pun (male, aged 66). Tara is a migrant from Bharse and, at the moment, he has been living in Butwal for more than 30 years. He has 
long professional experiences in private organizations. $\mathrm{He}$ is a social worker. He still has the memory of his origin community, Bharse. And, the third research participant is Surya Shrees (male, aged 53). Surya is also a migrant from Bharse and currently, working in a government office. He has been living in Kathmandu for more than 20 years. To maintain the anonymity, I have used pseudonyms of my research participants. To maintain confidentiality of research participants, the use of pseudonyms is required in research (Orb, Eisenhauer, \& Wynaden, 2001). On the basis of stories of these research participants, I have attempted to explore social, economic, environmental, and institutional threats of migration for the sustainable future. One way or others, the negative effects of migration are seen on these premises.

\section{Field Engagement and Methodological Pathway}

In this paper, the Bharse Village is the origin community, which is located in Gulmi District of Province 5 of Nepal. It is known as Bharse. And, it is also a hilly village, whereas Butwal and Kathmandu are the recipient communities, and they are known as Butwal and Kathmandu respectively. I have selected my research participants accordingly. To devise the stories of research participants, I got engaged in the field work from January to March 2017. I prepared this paper on the basis of three month's field work. In Bharse, I visited in the first week of January of 2017. In this visit, I had an interaction with the local people and selected a research participant from the origin community. At the same time, I took an opportunity to observe the migrational situation and its negative effects in Bharse. After that, I went to Butwal in the second week of January 2017. At first, I booked a hotel to make my station. From there, I talked with some migrants from Bharse on their phones. On that day, most of them had planned to go to observe Butwal Festival in Butwal. They requested me to come to that place, where the festival was being organized. I went there and met some of them. I unpacked my agenda with them about the purpose of meeting. Listening to me, they agreed to provide the information as per my requirements. I told them that I wanted only one research participant from Butwal with whom I could frequently consult for information. They anonymously proposed Tara Pun (male, aged 66). I repeatedly talked with Tara, till I could make up the final shape of my paper. In the research venture, I came back to Kathmandu. In Kathmandu, I had already known some migrants from Bharse. On the basis of their information, I talked with few of them but I selected Surya Shrees (male, aged 53) as a research participant from Kathmandu. Along with observations, I met him three times in the months of January, February and March of 2017. On the basis of conversations with Tara and Surya, I implored their personal experiences and perceptions about the negative effects of migration. I am also a part of this research journey. In Butwal and Kathmandu, I observed the social and economic life to oversee the negative effects of migration. In the same way, I took an opportunity to assess the condition of environmental degradation due to migration. In addition to this, during the field observations, I paid attention on disappearance of indigenous institutions as a consequence of migration.

To dig out the information of research premises, I employed ethnographic methods tailoring the qualitative research approach because the premises of ethnography are people's culture, their intuitions, perceptions and everyday behaviors as well as practices (Patton, 2002; Schech \& Haggis, 2002; Timseena, 2013). Particularly, I attempted to knit the stories on the basis of research participants' personal experiences and perceptions. And I prepared the ethnographic text. Hence, 'ethnography is a write up' along with engagement in the fields (Humpreys \& Watson, 2009). In this paper, the writing style is of ethnographic type. Particularly, enhanced ethnographic flavor is dominant to engender the stories (Humpreys \& Watson, 2009), because the text is described in a novel form. The techniques, I have employed, are conversational interviews and observations. However, the dominant approach of story collection is conversational interviews followed by observations to explore the negative effects of migration. The multiple reality is the ontological position (Noonan, 2008), because I attempted to capture the feelings of both non-migrants and migrants. For the epistemic purpose, dialogical interactions and discussions between researched and researcher were inculcated to coin the stories (Lincoln, Lynham, \& Guba, 2011). As an ethnographic researcher, I used 'personalized writing style' (Van Maanen, 2011), because I presented myself as a builder of stories of migrants.

\section{Migration and Social Doldrums}

Making a checklist for an ethnographic research in Kathmandu, I went to Bharse in the month of January 2017. I was there from $10^{\text {th }}$ to $15^{\text {th }}$ January 2017 . I spent six days with the local people of Bharse to interact with them. From Bharse, one of my research participants was Akash Thapa (male, aged 63). I began to interact with him to garner his stories. During the conversation, he shared that his forefathers had come to Bharse from the northern frontier for their better livelihood. I also found that the predecessors of present non-migrant of Bharse were immigrants into the lands of Bharse, who had entered there from the northern and southern frontiers (Kansakar, 1982; Shrees Magar, 2018), but nowadays immigration from other places to Bharse has not seen so far. Gradually, some of the succeeding generations began to leave Bharse. From the past to till date, many of them left Bharse and they have been living in intermediate locations, towns, cities and plain lands (Tarai). This does not mean, the village is totally empty but the point is that massive migration has been experienced in Bharse. Hence, migration continuously has been occurring in Bharse. Akash shared his experiences:

In my experience, migration of educated persons, rich people and skillful persons is high from Bharse because of this, the social vacuum is seen in the village. It has affected on social activities such as birth celebrations, marriage ceremonies and death processions. In the birth 
celebrations at the sixth day of birth of sons, relatives and neighbors used to come over and sing songs. They used to spend almost whole night entertaining themselves by singing, dancing, eating, drinking and cutting jokes in the midst. In the morning the family of infant child used to make offerings like some money and delicacies as the cost of celebrations. Nowadays, this tradition has been dying because in the village there are only a few people, and they do not perform the functions because of migration, population in the villager has become thinner. Relatives and neighbors just come to spend a few hours to share their wishes to infant child and parents.

This is a story, which shows the negative effects of migration on social heritages.

In the same sitting, he added:

I remember that in the past the gift of flowers used to be offered as best wishes. Nowadays, Khata has become a popular gift. In addition to this, wedding ceremonies used to be pompous in the village. Both the love and arranged marriage used to be commonly practised. Mostly, the cross-cousin marriage was in practice and it was popular too. It was a kind of pre-fixed marriage between the boy and girl. The decision of boys and girls used to be the final decision but parents of both families also used to make consensus for marriage. Assertively, it was a family-guided marriage in particular. Nowadays, such marriage practice is disappearing because of migration. Migration has forced to separate families and, living in the distance places, it is impossible to continue the cross-cousin marriage. In such a situation, it is almost impossible to maintain the traditional marriage practice. Besides this, in case of death of someone in the village, it is difficult to engage in the funeral procession because the village is almost empty.

From the past days to till date, many people left Bharse and even today some people have been leaving the village with 'the hope of making the life prosperous' (Paudyal, 2017). In the absence of educated persons, wealthy people and professionals, social doldrums have been seen in this village. Consequently, social heritages have been disappearing from everyday practices and, the traditional knowledge and skills have been vanishing from everyday practice. Loss of the traditional knowledge and skills is detrimental for ecosystem. In addition to this, the root of traditional knowledge and skills is culture. In some ways, encroachment on cultural heritages can bring survival challenge. Thus, migration of knowable persons created a challenge in protecting social heritages of Bharse.

During the field observation of Bharse, as an ethnographer, I found that rather than long-term thinking to preserve and protect the social as well as intangible assets, some people want immediate benefits from their physical and mental efforts and toils. Thus, they see chances of getting such tangible assets in other places after the departure from their village. In order to fulfill the immediate and material needs, quite a many have left Bharse. Due to such situation, social problems are appearing in their origin community, Bharse. Many traditional institutions and customs have been disappearing in recent days. Along with permanent migration, temporary migration has become considerably a serious issue in Bharse. Consequently, the only children, elderly people and women have become the protectors of houses and ancestral properties. From these groups of people only, it is not possible to protect traditional practices of the village. In the same observation, I found that in the past, the first day of the New Year used to be pompous in Bharse but, nowadays the scope of this celebration has been decreasing because in the village, due to huge migration of villagers, only some people are left in the village. Even those people, who are living in the village, cannot organize the event grandiosely. It is unlikely that the migrants would come and organize the event there again.

In conversation, Akash gave a reference about Dashain and Tihar Festivals. In the past, the village was full of people. Even from the cities and foreign countries, the temporary migrants used to come home in the name of celebrating these grand festivals. The relatives and kin groups from the distant locations used to come to receive offerings and blessings of the Dashain from the hands of elderly persons of the family, especially grandfathers or parents. In addition to this, men from the cities and foreign lands used to come back to celebrate Tihar festival. They particularly used to receive Tika and blessings from sisters. Traditionally, males were eligible to leave the homes whereas females were the protectors of houses and caretakers of children. Aubriot (2009) remarked that as the male workforce now works away from the village, many households are run by women, who are thus de facto temporarily heads of households. In absence of males, the festivals were the platforms of social gathering of family members and relatives, which used to be a catalyzer of social grooming. Nowadays, the only a few people are living in the village due to massive migration. If this trend continues, one day the village is going to be a deserted place. The permanent migrants do not come to village to celebrate the festivals because they have been living in the new places with their families and relatives. Rather than coming to Bharse, the migrants engage to celebrate with the local people of the recipient communities, where they have settled. And, there are very few temporary migrants of the village. Those temporary migrants come home but they are quite a few in number. Nowadays, the celebrations of festivals cannot be jubilant in Bharse in comparison to past days.

In the same conversation with Akash, I found that in the Dashain and Tihar festivals, youths of the village used to carve bamboo and wooden swings. Especially, young boys, girls and even children used to get together and play swings in an open space of the village. They also used to sing songs and perform dance in the groups. On these special days, they used to spend day and night together. It was a good time to get to know each other and find out the best suitor in some ways. Nowadays, due to migration, there are not skillful persons, who could make swings. Without making swings, there is not any point of gathering in the open spaces of the village. Gradually, such social heritages of the village have been dying. 
In addition to this, arable lands of Bharse are being converted into barren lands or green deserts. The local knowledge and practices, and institutions related to farming have been disappearing from everyday practice because of migration of great many people from Bharse. Even, the local people have been cutting out the numbers of domestic cattle at home, which I found from the field observations of Bharse. Vanishing such customary practices is a challenge for sustainability. Unless and until the local as well as social heritages are preserved or protected, a threat for survival always remains there.

After the field work of Bharse Village, I came to Butwal on $16^{\text {th }}$ January 2017. I spent five days in Butwal from $16^{\text {th }}$ to $20^{\text {th }}$ January 2017 . After I came to Butwal, I met some migrants from Bharse. One of them is Tara Pun, who is residing in Butwal at the moment. On the basis of his availability, I selected him as a research participant. After this, I went to meet him in his house. Just reaching there, I unpacked the purpose of meeting. In the conversation, he expressed that after landing in Butwal, he has been enjoying material life but he could not perform cultural practices of his birthplace, Bharse living in Butwal because he did not get space to perform it. In Butwal, he has developed the network with the new groups. Making a network is a prerequisite of migrants (Coleman, 1988; Putnam, 2000). He began to engage with the local people but it is not easy for him to adapt with the new cultural practices. Additionally, Tara is fed up with the overcrowded condition of Butwal because like him, there are many other migrants. Hence, migration is very often an act of desperation in the new community (Inchley, 2014), because the new contexts demand new knowledge, skills and ideas to adjust. The other way around, Tara's arrival in Butwal also occupies a space. Like Tara, many migrants have come to live there. Thus, the space is becoming narrow and there is over pressure on resources as well. Other than conversations with Tara, I observed the migrational situation of Butwal. Butwal is a central hob of Lumbini Zone, where migrants from various parts of Nepal have come to run their businesses and settle there. In such a situation, it is impossible to know local people and migrants, and their social behaviors. In addition to this, I have added the following words of Tara. Furthermore, he said:

In Bharse, there were not any unknown villagers and neighbors. I was familiar to all of them but in Butwal, there are many unknown people. Many other people also do not know me. Particularly, I know fellow migrants and close neighbors. Because of high density of people in Butwal, I am really sinking into Human Ocean. Such situation occurred due to natural growth of local people and arrival of migrants from other parts of the country. Thus, I am unfamiliar to other people's behaviors, their ritual practices and the patterns of living.

Particularly, Tara became stranger for local people and other migrants in Butwal. The other way around, other people also became strangers for Tara because all of them came from different cultural background. Furthermore, he added:

In the initial days of arrival in Butwal, I felt awkward in speaking, having new food items and engaging in social functions. Peoples' ways of expressions and interactions, and food consumption habits were totally different in Butwal in which I was totally unknown. Many social functions or events, that were celebrated, were totally new to me because there were different ways of performing and celebrating such functions. In such a state, I neither could perform the social behaviors of Bharse nor could I fully adopt the local practices of Butwal. Even today, I am standing at crossroads.

Listening to story of Tara, in Butwal, he was at fragility. Coming from a narrow space, Tara has been delving into big space. Many times, an individual is considered as a part of the whole system or an individual is the weakest part in front of system (Giddens, 1986). As an individual, Tara is a small part of big society, Butwal. Hence, society is a whole of both local people and migrants. Hence, Butwal became the recipient community of many migrants, where other migrants also come to live. Physically, he has been living together with the local people and other migrants but socially, all of them come from different contexts and practices. They all are new to each other. Hickman (2005) mentioned that the migrants live up hybrid life and they remain unsettled state in the new community. In such a diverse society of Butwal, it is not possible to protect social heritages and to perform their behaviors. Even from the story of Tara, I found that he neither could maintain his old traditions of Bharse nor he could adopt the new practices of Butwal. He has been living up dual life. In the initial days, Tara was badly treated in Butwal because he was totally unknown about the local systems of the new place, Butwal. He did not feel welcoming. Inchley (2014) also remarked that the migrants are often treated badly. More often, the local people have a kind of superiority feelings over newcomers, which is a bad social treatment. In addition to this, Tara often became a victim of exclusion by the host society, being segregated in social functions or activities because of ethnocentric feelings. The deep fault line that divides human society between the local people and the migrants or old and new pose a major threat to prosperity, security and stability in the human society, which is a challenge for sustainable future.

\section{Migration and Economic Fragilities}

Living in my relative's house, I observed the economic situation of Bharse. It was the third day of my field visit in the first week of January 2017. Even personally, I also was familiar to subsistence economy of the rural contexts of Nepal. The people of Bharse have been practicing subsistence economy since the time immemorial. The main occupation of people of Bharse is farming. Almost all of them engage in farming related activities. The agro-based economy of Bharse is the main source of livelihood. While some people rose up from the farming occupations and made their economic situation better, they look for further opportunities in other places, which became possible after 
migration from Bharse. Those people, who had capacities of contributing to the local economy, tend to migrate from the village. In the absence of such economically active people, the economic activities of the origin community have become low and slow. In other words, migration from Bharse is making the settlement thinner in the village. The lower number of people engage in lower economic activities. In Bharse, I talked with Akash Thapa (male, aged 63). Furthermore, he shared his story:

What I see is, due to downward migration of wealthy people of Bharse, the economic activity has been lowering in the village because the only people of poor strata have remained there. The migrants left village along with their properties, knowledge and skills. They went away with both tangible and intangible assets. The rapid migration from Bharse is on the rise even today. Because of this, instead of economic prosperity, the economic condition is going down. The local people, like me, cannot bring significant change in the local economy because of lack of knowledge and skills of utilizing the local resources, which are around them. Even, it is unlikely to bring resources from other places to boost up their economic status.

Listening to the story of Akash, I found that those people, who were economically sound in Bharse, left the village. This has caused economic doldrums in the village. After the field work of Bharse, I went to Butwal in the second week of January 2017. Making the station in the hotel, I met research participant and observed their situations. In Butwal, I found that after the departure from Bharse, the economic conditions of migrants became relatively better but it became lower than the economic condition of their local counterparts of Butwal. Thus, the economic inequality among migrants appears in Butwal. In addition to this, some migrants have contributed to the local economy and many of them have contributed to create economic inequality there, because of them, more resources need to be acquired for their survival. In a way, migration is believed to have increased inequalities in the society (de Haas, 2010), because migration is a process of sharing the resources. The division of existing resources brings economic challenge. In the third time, I talked with Tara Pun (male, aged 66). In this meeting, he shared his experiences:

Economically, I have been living normal life in Butwal. Like me, some of my fellow migrants have been living with the limited amount of money and resources. Coming to Butwal, it was not possible for me to boost economy at the speed of rocket science. I have been experiencing the economic gap between Butwal and Bharse. The economic situation became lower in Butwal in comparison to local counterparts but it was relatively better situation in Bharse in comparison to local counterparts. Thus, I could not make big shift in the economic status in comparison to local counterparts. The job, in which I had engaged, supported me just for survival.

On the basis of story of Tara, he did not have sufficient money. So, he is not making his life considerably better. The money guided life of Butwal brought economic hurdles in him. Essentially, the migrants may well evoke the pain of loss of old behaviors and practices in the process of making economic condition better, and not being firmly habitual in the cities so far (Satterthwaite, 2015). The story of Tara also revealed that the different economic practices of Bharse and Butwal are always a problem for him because the economic realms vary from one place to another. In the month of February 2017, I talked with Surya Shrees (male, aged 53) in Kathmandu. In this conversation, he shared a story:

The economic condition of my family was better in Bharse. After migrating from the village, the economic condition became relatively better in Kathmandu but in comparison to other local people or in the local context, my economic condition is relatively lower. As a newcomer, I did not have much chance to make better economic growth.

On the basis of Surya's story, his economic condition became relatively better in Kathmandu after the departure from Bharse. Even, his economic condition was better in Bharse in comparison to his local villagers. After his settlement in Kathmandu, the economic situation did not change much. It is not logical to compare the economic situation of Bharse with the economic situation of Kathmandu. Relatively, Surya improved his economic situation better in Kathmandu than in Bharse but this was lower in comparison to the local counterparts of Kathmandu.

In addition to this, accumulating excessive resources by some people create a situation of emptiness in some or other places. Such high gobbling attitude creates inequality in the society. Such habits should be changed to feed all people of earth. Particularly, the present generations should open the hearts to preserve resources for future generations' survival. World Commission on Environment and Development [WCED] (1987) also agreed that the needs of the present generations should be met without compromising the ability of future generations to meet their own needs. Without considering this reality, one day, our future generations can be empty handed. Thus, greedy behaviors of human beings may put a question mark in sustainability because of some systematic failures of authorities and consumable habits of mankind (Zadek, Forstater, \& Naidoo, 2012). Even the concerned authorities do not pay well attention on the one hand, and on the other hand, human beings have greedy attitudes of consuming the resources more than their needs. The high ambition of accumulating resources leads to encroachment upon natural resources. There are poor people, who underutilize the resources because they do not have access to them. In addition to this, the globalization has created a gulf between the rich and the poor. The rich people are becoming richer, as they have been taking optimum benefits from globalization but the globalization offers nothing to the poor (Middleton \& O'Keefe, 2001). The rich ones use high resources and the poor have only few things to eat and utilize. Desperately, the poverty situation can lead to social chaos and environmental degradation. In some ways, migration leads to overconsumption of 
resources for which invasion upon resources is the only action. Such situation is a threat for sustainable future.

\section{Effects of Migration on Natural Environment}

During the field visit of Bharse in the month of January 2017, I attempted to observe the situation of environmental degradation. I found that because of migration, less number of people have been living in the village or the number of people in the village has become thinner. As a result, the volume of forest lands has been increasing there. The higher chunks of people require high amount of resources so they used to cut trees or woods and fodders from the forests. While the greater number of people migrated, some chunks of lands became barren. Some of them became thick forests and the other chunks of lands became grasslands. However, in the name of development, the road construction project in some parts of the village has been launched and, consequently trees have been cut down to open the road track. And, the big rocks were broken. The land pattern in some parts of the village has been excavated using excavator machines, which have been leading to landslide, unseasonal rainfall, drought, dry up water source and low agro-products in the village. In the monsoon season, the landslide has washed away the fertile lands located at the bank of the streams. Likewise, the unseasonal rainfall ensued untimely farming with low productions of eatables. Besides this, in the winter season, the drought has caused low agro-products. Sometimes, the monsoon begins late, which causes late plantation of crops. The dry water source resulted scarcity of drinking water for human beings and animals. Those people, who were conscious about the local environment, migrated from Bharse. In their absence, encroachment upon natural environment or resources has been increasing but it does not mean, the local people have distorted the environment and resources. The question is that they are less aware. In this regard, Akash Thapa (male, aged 63) added his personal experience:

Nowadays, in the name of opening the road tracks, the villagers have been haphazardly digging out the lands. Due to this, the sources of water have been bogging down as well as moving down to lower surface level. Due to this, the scarcity of water source has been seen on the upper elevation of the village. The new road track had led to landslide, which has wiped out the habitat of water creatures of the stream. In addition to this, nonrenewable objects such as plastic, bottles and pesticides are also being used in the village. After their usage, these materials have been thrown here and there haphazardly, which have created an environmental threat in the village. This has been happening because of the earning motive of some people. Those people, who could control as well as manage such misbehaviors, migrated from the village. Moreover, most of the educated persons have been leaving the village, who could raise awareness about the land encroachment to protect natural environment. In my feeling, the departure of the knowledgeable persons created a vacuum in the village. As a result, the situation has become worse.
From the conversation with Akash, I came to know that those people, who were conscious about the natural environment, have been leaving from Bharse. The local people seem to be less conscious in protecting and preserving the natural resources as well as environment. They mostly want to exploit the resources to fulfill their current needs. Such habits can be harmful for future generations. In addition to this, in the third week of February 2017, I went to Butwal. This was my second visit. After the confirmation of the time from the mobile conversation, at a tea stall, I met Tara Pun (male, aged 66). In this meeting, I opened an agenda to discuss about the effects of migration on the natural environment. In this informal conversation, he expressed his experiences:

At that time, while I arrived in Butwal, I saw a lot of lands covered by the forests. The forests in Butwal used to be full of trees and vegetation. Overtimes, these trees of the forests have been cut down and, some chunks of lands have been converted into farmlands to produce food for growing population. Such deforestation has caused to kill wild animals, insects and snakes, which were the protectors of environment by eating harmful as well as unnecessary things. Nowadays, the big chunks of lands have been divided into small plots and, houses are being built there. In the same way, the roads in the interior parts of Butwal also have been opened for vehicle movement. In addition to this, there are very few trees at the road side. In the name of widening the roads, they were cut down. There are very few trees planted in the house compounds.

According to Tara, to fulfill the current needs, people have been wiping out forest resources because every year, the density of population has been increasing in Butwal because of migration from proximities and different parts of the country. In a way, migration has been contributing to make high density of population. Tara further added:

In the past, there were few vehicles in Butwal, and the noise pollution was less. Along with increment of migrants, every year, the number of vehicles has been increasing, which has created noise pollution there. For the movement of these vehicles, the size of road needs to be wider in Butwal. For this, the size of land has been decreasing leading to congested society.

On the basis of Tara's story, the trend of migration has been increasing in Butwal but the volume of land size has been decreasing. And, the space has been becoming narrow. Such a situation has been creating the gulf between human needs and resources. Tara further shared another story:

Still I remember that some years before, water of the Tinau River was clean. Nowadays, the river bank and water of Tinau have been polluted because of human wastes. The river bank has become a dumping site of garbage because the migrants have been increasing in Butwal and its surrounding areas. On the one hand, the increment of people means to increase the wastages. On the other hand, the high density of people produce high amounts of wastages. These wastages have been thrown in the river. People not only throw household 
wastages but also they throw wastages of vegetables and animal butcheries. These have created an environmental pollution in Butwal.

According to Tara's story, the migration-induced environmental threat has been increasing every year in Butwal. The deforestation inculcates a challenge in the oxygen formation for human health as well. And, it causes the killing of wild animals, insects and snakes, who are the protectors of environment. Nowadays, an attempt has been made to overtly link migration with environmental change (International Organization for Migration [IOM], 2009), because migration has a close connection with the natural environment. Assertively, it also has a correlation with resources. Besides this, the environment is just one of the factors that influences mobility of people, and it is by means the most important attribute (Massey, Axinn, \& Ghimire, 2007). Besides this, the resources of one place are imported and exported to other places for human consumption. Some people overused and consumed the high amount of resources and the others have underused the resources. In some places, there are over stockpile of resources and in other places, there are dearth resources. Over and excessive consumption of resources creates inequalities in the society. A figure shows that 80 percent people consume 20 percent resources. On the contrary, the 20 percent people consume 80 percent resources of the globe, as the consumption patterns of the first world countries are very high (Rogers, Jalal, \& Boyd, 2008). Both overuse and underuse of resources brings inequality in the society posing a threat for human beings. Thus, migration brings economic fragilities in both origin and recipient communities.

\section{Disappearing the Social Institutions}

In the first week of January 2017, while I was in Bharse, I attempted to explore the effects of migration on social institutions. Talking with Akash Thapa (male, aged 63 ) on $4^{\text {th }}$ January 2017 , I found that because of migration, the social institutions have been crumbled. Robbins (1998) remarked that the transformation and dismantling of social institutions is best represented in changes over times. In a way, migration created such a situation that the local people have been giving up practising social values, norms and systems, and customary practices, which are parts of social institutions in Bharse. In the conversation, Akash recalled his memory and shared a story:

Especially, in the crop planting and harvesting seasons, people of Bharse used to form informal groups such as Parma (a small group of farmers formed among two or three persons to exchange labour work) and Hudda (a seasonal association of large groups of farmers formed to exchange labour work). In the Parma system, people would form small groups of people consisting of two or three or four individuals but in the Hudda system, there used to be many young boys and girls. They used to practise on rotation basis. Starting from the first member, the turn would go up to the last member. After that, it would follow the same process repeatedly. The rotation used to be defined on the basis of lottery system or consensus or urgency of members. Sometimes, they used to take turn before and after the fixed date or time depending on urgency. Due to huge chunks of people's migration, only some people live in the village, and nowadays they do not perform and practise Parma and Hudda systems. Thus, the existence of Parma and Hudda systems has disappeared from the practice.

Listening to story of Akash, the social institutions have been vanishing because of downward migration from Bharse. It is not the situation that the lower number of local people could protect and preserve the social institutions. My argument is that where there is lower number of people, the systems also begin to vanish. Particularly, quite a huge number of people is required for Hudda. Nowadays, those numbers cannot be found. Thus, one of the causes of dissolving the social institutions is migration. In addition to this, in the month of March 2017, in Kathmandu, confirming the time of meeting with Surya Shrees (male, aged 53), I went to his home in the morning on $20^{\text {th }}$ March 2017. In the meeting, he shared his versions:

Living in Kathmandu, I have experienced that the situation, which is far more different than that of Bharse. In the origin community, people had a sense of togetherness and common practices. Particularly, in the marriage ceremonies and death processions, relatives and neighbours used to come to help the concerned family. Some of them used to help family for the household chores and the others used to help for the external works. In the interior work, they used to help family to prepare food for invitees on the special day whereas in the external work, they used to help family in collecting grasses, fire woods and food items in Bharse but in Kathmandu, the situation is totally different. For the marriage ceremonies, the function is organized in the party palace. All relatives and acquaintances are invited in that place. Even, on the day of purification of death ritual, the event is organized either at home or community building of the nearest location. The relatives and neighbours are invited to a place, where the event is organized. In addition to this, I have experienced individualistic and self-centric life in Kathmandu leaving the collective life or grooming of Bharse. Living in the new community, it is almost impossible to practise and perform the old institutional values and norms alive. On the other hand, it is not easy for me to accept and practice the new rules, regulations and systems of the new community wholeheartedly.

On the basis of story of Surya, I found that migration brought a challenge to preserve and protect the social institutions of the origin community, on the one hand, and on the other hand, there is high pressure on social institutions of the recipient community. Such damage of social institutions causes disappearance of social values, norms, rules, regulations, and systems, which always invites a threat for sustainable future.

\section{Insights}

Apparently, migration is a never-ending issue. It had happened yesterday; it has been happening today; and it 
will happen tomorrow too. Thus, migration is not 'one stop shop' (Benton, McCarthy, \& Collectt, 2015), as it is a continuous process (Subedi, 1988). In such a situation, I explored the negative effects of migration on social, economic, environmental and institutional avenues of society because migration does not stand alone; as it is entrenched in these avenues. In other words, migration is not a challenge free entity. It encompasses multiple challenges in both origin and recipient communities, which were the fields of study. Considering this reality, I envisaged the negative effects of migration on social heritages, economic systems, natural endowments and institutional systems putting my positionality on 'the migration pessimistic school of thought' (de Haas, 2014). Without paying attention on negative effects of migration on social, economic, environmental and institutional facets of both origin and recipient communities, the scope of migration studies was incomplete. On the basis of these ideas, I see the threats of migration for our sustainable future because encroachment upon social, economic, environmental and institutional avenues brings detrimental situation in the human society in the long-run. Thus, preserving and promoting these assets comes under the shoulders of present generations.

\section{Acknowledgements:}

I must be thankful to Ram Kumar Thapa and Sanjay Kumar Pun for checking the language of my paper. Likewise, thanks go to my research participants for sharing their stories.

\section{Funding:}

No funding

\section{Ethnical Approval:}

I took consent from the research participants for their information. I have not misused the stories of research participants.

\section{Conflict of Interests:}

This is my original paper. For citations, I have recognized and acknowledged all authors through references.

\section{Ethical Conduct of Research:}

In the research process, I respected the cultural practices of research participants and their communities. In addition to this, I paid attention on gender, caste, belief, religious and geographical sensitivities. I have complied the standards and requirements of the journal.

\section{References}

Aubriot, O. (2009). International and national migrations from a village in Western Nepal: Changes and impact on local life. European Bulletin of Himalayan Research, 35(36), 43-61.

Benton, M., McCarthy, H., \& Collectt, E. (2015). Into the mainstream. Rethinking public services for diverse and mobile populations. Migration Policy Institute (MPI).
Central Bureau of Statistics [CBS]. (2014). Population monograph of Nepal. Central Bureau of Statistics. Government of Nepal, National Planning Commission Secretariat, Author.

Coleman, J. S. (1988). Social capital in the creation of human capital. The American Journal of Sociology, 94, 98-120.

Creswell, J. W. (2007). Qualitative inquiry and research design. Choosing among five approaches ( $2^{\text {nd }}$ Ed.). Sage.

de Haas, H. (2010). Migration and development: A theoretical perspective. International Migration Institute (IMI), University of Oxford, London, UK.

de Haas, H. (2014). Migration theory: Quo Vadis? International Migration Institute (IMI), University of Oxford.

Gartaula, H. N. \& Niehof, A. (2013). Migration to and from the Nepal Tarai: Shifting movements and motives. The South Asianist, 2(2), 29-51.

Giddens, A. (1986). The constitution of society: Outline of the theory of structuration. Policy Press.

Gurung, H. (2001). Highlanders on the Move: The migration trend in Nepal. In S. von der Heide and T. Hoffmann (Eds.), Aspects of migration and mobility in Nepal (pp. 11-42). Ratna Pustak Bhandar.

Hickman, M. J. (2005). Migration and diaspora. In J. Cleary \& C. Connolly (Eds.), The Cambridge companions to modern Irish culture (pp. 117-136). Cambridge University Press. https://doi.org/10.1017/ CCOLO52182009X.007

Humpreys, M. \& Watson, T. (2009). Ethnographic practices: From 'write up ethnographic research' to 'writing ethnography'. In S. Ybema, D. Yanow, H. Wels \& F. H. Kamsteeg (Eds.), Organizational ethnography (pp. 40-55). Sage.

Inchley, V. M. (2014). The Nepali diaspora. Migrants, ministry and mission. Ekta Books.

International Institute of Migration [IOM]. (2009). Migration, environment and climate change. Assessing the evidence. Research and Publication Division, International Organization for Migration. Author.

Kansakar, V. B. S. (1982). Emigration, remittances and rural development. Center for Economic Development and Administration (CEDA), Tribhuvan University, Nepal.

Lee, E. S. (1966). A theory of migration. In Demography, 3(1), 47-57.

Lincoln, Y., Lynham, S. A., \& Guba, E. G. (2011). Paradigmatic controversies, contradictions and emerging confluences, revisited. In Norman K. Denzin \& Yvonna S. Lincoln (Eds.), The Sage handbook of qualitative research (pp. 97-128). Sage.

Massey, D. S., Axinn, W. G., \& Ghimire, D. G. (2007). Environmental change and out-migration: Evidence from Nepal. Population studies center research report. Population Study Center, University of Michigan, Institute for Social Research, USA.

Middleton, N. \& O'Keefe, P. (2001). Redefining sustainable development. Pluto Press. 
Noonan, J. (2008). Ontology. In Lisa M. Given (Ed.), The Sage encyclopedia of qualitative research methods ( $\mathrm{pp}$. 577-581). Sage.

Orb, A., Eisenhauer, L., \& Wynaden, D. (2001). Ethics in qualitative research. Journal of Nursing Scholarship, 33(1), 93-96.

Parajuli, M. N. (2008). Schooling: The way people see it. In Gnawali, L. (Eds.), Journal of Education and Research, 1(1), 31-40).

Patton, M. Q. (2002). Qualitative research and evaluation methods (3rd ed.). Sage.

Paudyal, P. K. (2017). Reintegration of returnee migrant workers in home country: A convergent mixed methods study. (Unpublished dissertation of master of philosophy). Kathmandu University, School of Education, Dhulikhel, Nepal.

Putnam, R. D. (2000). Bowling alone: The collapse and revival of American community. Simon and Schuster.

Ravenstein, E. G. (1889). The laws of migration. Journal of the Statistical Society of London, 48(2), 167-237.

Rogers, P. P., Jalal, K. F., \& Boyd, J. A. (2008). An introduction to sustainable development. Earthscan.

Satterthwaite, D. (2015). Urbanization, urban poverty and rural-urban migration. International Institute for Environment and Development (IIED), Geneva.

Schech, S., \& Haggis, J. (2002). Culture and development. A critical introduction. Blackwell Publishing.

Shrees Magar, M. (2018). Bharse-Arkul Rajyako Itihas [History of Bharse-Arkul State]. Jeeban-Ganga Kalyan Kosh, Kathmandu.

Subedi, B. P. (1988). Continuity and change in population movement: The case of Nepal. Population Geography, $10(1 \& 2), 28-41$.

Subedi, B. P. (1993). Continuity and change in population movement: From inside a rural Nepali community. (Unpublished doctoral thesis). The University of Hawaii, USA.

Timseena, B. (2013). Musings on ethnographic field work. Nepalese Journal of Qualitative Research Methods, 5, 9-16.

Van Maanen, J. (2011). Tales of the field. On writing ethnography (2nd Ed.). The University of Chicago Press.

World Commission on Environment and Development [WCED]. (1987). Our common future. Brundtland Commission. Oxford University Press. Author.

Zadek, S., Forstater, M., \& Naidoo, S. (2012). Shaping a sustainable future. Strengthening the role of development cooperation in delivering sustainable development. UN Development Cooperation Forum, New York, USA.

Lal Bahadur Pun is pursuing $\mathrm{PhD}$ from Kathmandu University, School of Education on the issue of migration. He earns expertise on migration, development and cultural studies.

Email: lalbpun@yahoo.com 